\title{
The Academic English Language Needs of Industrial Design Students
}

\section{in UiTM Kedah, Malaysia}

\author{
Nor Aslah Adzmi \\ Department of Language Studies, Universiti Teknologi MARA Kedah \\ PO Box 184, 08400 Merbok, Kedah, Malaysia \\ Tel: 6-012-474-9242Ｅ-mail: aslah787@kedah.uitm.edu.my \\ Samsiah Bidin \\ Department of Language Studies, Universiti Teknologi MARA Kedah \\ PO Box 184, 08400 Merbok, Kedah, Malaysia \\ Tel: 6-019-418-8633 E-mail: samsiah482@kedah.uitm.edu.my \\ Syazliyati Ibrahim \\ Department of Language Studies, Universiti Teknologi MARA Kedah \\ PO Box 184, 08400 Merbok, Kedah, Malaysia \\ Tel: 6-013-436-2404Ｅ-mail: syazliyati@kedah.uitm.edu.my \\ Kamaruzaman Jusoff (Corresponding author) \\ Faculty of Forestry, Universiti Putra Malaysia \\ 43000 Serdang, Selangor, Malaysia
}

Tel: 6-03-8946-7176 E-mail: kjusoff@yahoo.com

\begin{abstract}
The purpose of this study was to analyse the academic English language lacks and needs of Industrial Design students in Universiti Teknologi MARA Kedah (UiTM). It highlights the lacks and needs for English for Academic Purposes in helping the students to succeed in the program through the usage of English language. The research tools used were in the form of a questionnaire and interview which later being computed using SPSS into data analysis. Results indicated that the students have problems in acquiring the English language skills. This shows the weaknesses of English Language courses in helping the students to acquire the language skills needed by the faculty. The study concludes that relevant actions should be taken as to ensure the needs of the students are fulfilled and they can perform effectively in the program and future career.
\end{abstract}

Keywords: Academic English language needs, Needs analysis, Industrial design

\section{Introduction}

Many institutions of higher learning provide students with ESP, EAP and EOP courses in order to provide them with the exposure to a different kind of English language from the kind they had learned in schools. In UiTM, English language is the medium of instruction. Since English language plays such a vital role, the university thus make English language courses as compulsory subjects to be taken by semester 1 (BEL100), 2 (BEL200), and 3 (BEL250) students and are taught as General English. The analysis of the students' English courses' results of every academic semester indicate a high failure rate that is found to persist, in particular, among the Industrial Design students. This has also contributed to their bad performance in their specialized courses. The English language courses may have not given them what they actually need to ensure their success in the academic context or specialized field. The current English language courses only expose them to the four major skills generally. They face difficulties in coping with these courses as the faculties also require the students to have other relevant skills such as presentation or public speaking skills, report writing or product report skills and other skills that are applicable in their respective programs.

This raises the issue of suitability of the courses as far as the students are concerned since generally there is no specific course that can cater to the demands of a specific program. Therefore it is important to consider the program needs to ensure the students' success in the academic setting. Another issue is whether these courses adequately prepare the students to function according to their specializations.

Khairi Izwan Abdullah et al. (1993) indicate that the progress of ESP courses in institutions of higher learning is due to the fact that it is highly recommended by the universities for the greater specificity that it holds. Seedhouse (1995) 
states that needs analysis is rarely carried out in the General English classroom even though it is not possible to specify the needs of General English learners. He further adds that need analysis is very much related to ESP but has been neglected in the General English classroom. This is in line with Hutchinson and Waters as cited in Seedhouse (ibid), who indicate, "what distinguishes ESP from General English is not the existence of a need as such but rather an awareness of the need...for the time being, the tradition persists in General English that learners' needs can't be specified and as a result no attempt is usually made to discover learners' true needs". Blue (2006) states that the needs analysis may help us to specify a number of language functions that occur frequently in certain contexts in which art and design students are expected to operate. According to Jordan (1997:23), there are questions that need to be asked when preparing EAP syllabuses. The questions include whose needs are to be analyzed (the students; the sponsor's institution or country; the specialist department and so on), the specific English requirements that a faculty wants its students to master, the kind of English language skills that are prioritized as more important than others and the qualifications that the English language teachers/lecturers should have.

Therefore, it is pertinent to know the specific English language lacks and needs among the Industrial Design students. This is to make them aware of the required skills to function effectively in their future roles as designers upon graduation. Besides, they also have to function effectively within the program itself since the competition among them is high. Hence, this study attempts to investigate the English language needs of Industrial Design students undertaking the English for Academic Purposes (EAP) course in an institution of higher learning, in particular the UiTM Kedah.

The objectives of the study are two-folds which are to identify the academic English language skills that the Industrial Design students lack based on the perceptions of the Industrial Design students, subject-specialists and English language instructors and to identify the academic English language skills needed by the Industrial Design students based on the perceptions of the Industrial Design students, subject-specialists and English language instructors.

\section{Method}

The design of this study is descriptive non-experimental and it employs the Needs Analysis techniques. Questionnaires were used to run a survey among the Industrial Design students, the Industrial Design instructors, and an interview was conducted to the English language instructors who teach the Industrial Design students. The researchers employed the needs analysis framework by Dudley-Evans and St. John (1998:125) because it can be viewed as the most comprehensive needs analysis introduced recently (Figure 1).

\subsection{Sampling Design}

The sampling of this study consists of 54 respondents: a) 41 Industrial Design students who are in Semesters 4 and 5 and have been exposed to all the three English language courses required by the university. b) 7 Industrial Design instructors (subject-specialists) who teach the upper semester level students and are also academically qualified instructors with more than 10 years of teaching experience. c) 6 Industrial Design English language instructors who teach the Industrial Design students or have had the experience of teaching them and are also academically qualified English language instructors.

\subsection{Research Instruments}

With the help of subject-specialists, the researchers identified areas of reading, writing, speaking and listening skills that the students must acquire in order to be competent in their program. The researchers developed two sets of questionnaires adapted and adopted from studies done by Wan Irham Ishak (2002) and Suzana (2005). The two sets are meant for the Industrial Design students (Set A), and the Industrial Design instructors (Set B). Both Set A and Set B are divided into two parts; Part 1 is designed to gain some information about the respondents while Part B is designed to gain information about the four skills (Reading, Writing, Speaking and Listening) and two language components (Grammar and Vocabulary) which all are later divided based on three criteria which are: i) frequency of specific skills used in the program; ii) ability to perform such skills and iii) the extent to which English courses help them perform the skills effectively. To the English language instructors, the researchers conducted an interview to elicit their perceptions on the students' general language ability and also the suitability of the English language courses offered to the Industrial Design students.

\subsection{Research Design}

The respondents were asked to rank from 'Not Important' to 'Very Important' for the importance of each general language skill/component, from 'Never' to 'Always' for the frequent use of specific skills, and from 'Not At All' to 'A Lot' for the extent the English courses help to perform the skills. For ease of quantification on these two aspects, the researchers used percentage. The four-point Likert-type scale was used to construct the questionnaires on general language ability and the ability to perform the specific skills (from 'Bad' to 'Very Good'). The high values (3 or 4 on a 1 to 4 Likert scale) can be interpreted as having high performance/ability and low values (1 or 2$)$ as having low performance/ability. To quantify the researchers used the statistical procedure mean in order to get the average score for each specific skill. 


\subsection{Data Analysis}

The responses from the questionnaires were tabulated and analyzed using the Statistical Package for the Social Sciences (SPSS) version 12.0. The statistical procedures used were the descriptive statistics - mean and percentage.

\section{Results}

\subsection{The Students' Views on Their Language Lacks and Needs}

3.1.1 Students' perceptions on the importance of each general language skill/component and their own general language ability

Majority of the students rated Speaking Skill (75.6\%) as the most important skill to be acquired by them, followed by Grammar (53.7\%), Vocabulary (48.8\%), Listening (43.9\%), Writing (39.0\%), and Reading (34.1\%).

In evaluating their own ability in regards to each skill, the students perceived themselves to be rather good in Reading with the mean score of $(M=3.00)$, followed by Listening $(M=2.71)$ which can be considered as above average and the rest of the skills (Speaking $(M=2.49)$, Writing $(M=2.46)$, Vocabulary $(M=2.41)$, Grammar $(M=2.24))$ as just average.

3.1.2 Students' perceptions on the frequent use of the specific reading skills required in their program, ability to perform the skills and the extent the English courses help them to perform the skills.

Based on the questionnaire, the students ranked the frequent use of the specific reading skills required in their program as follows (from 'Always' to 'Never'): Posters, Technical Reports, Company Brochures/Pamphlets, Management Reports, Information Booklets, General interest articles, MOU (Memorandum of Understanding), User Manuals, Sales-related materials, Official Notices, Formal Business Emails (34.1\%), Business letters, Specialist Articles (Table 1).

By using the descriptive statistic mean, the researchers tabulated the students' perceptions on their ability to perform the specific reading skills. The results reveal that the highest scores are just above average for such skills, Posters $M=2.98$, Company Brochures/Pamphlets $M=2.83$, Official Notices $M=2.98$, Technical Reports $M=2.76$, Information Booklets $M=2.71$, User Manuals $M=2.71$, and General Interest Articles $M=2.68$. The lowest ability is in Business Letter $(M=$ 2.39) (Table 1).

As for the extent the English courses help the students to perform the skills, the results is as follows (from 'A Lot' to 'Not At All'): Information Booklets, Posters, Company Brochures/Pamphlets, Specialist Articles, General Interest Articles, User Manuals, MOU, Technical Reports, Business Letters, Official Notices, Management Reports, Sales-Related Materials, and Formal Business Emails (Table 1).

3.1.3 Students' perceptions on the frequent use of specific writing skills required in their program, ability to perform the skills and the extent the English courses help them to perform the skills.

The students' perceptions on the frequent use of the specific writing skills required in their program were ranked as follows (from 'Always' to 'Never'): Posters, Technical Reports, Management Reports, Information Booklets, Company Brochures/Pamphlets, User Manuals, Sales-Related Materials, Official Notices, General Interest Articles, Specialist Articles, Business Letters, and Formal Business Emails. (Table 2).

Regarding the students' perceptions on the ability to perform the skills, the results reveal that there are only three specific skills which recorded to have mean scores above average which are Posters $M=2.78$, Technical Reports $M=$ 2.63, and Information Booklets $M=2.56$. The skill with the lowest ability is User Manuals ( $M=2.22)$ (Table 2).

To what extent the English courses help the students to perform the skills, the students ranked the specific skills according to 'A Lot' to 'Not At All': General Interest Articles, Management Reports, Posters, Company Brochures/Pamphlets, Technical Reports, Specialist Articles, Information Booklets, Business Letters, Official Notices, Formal Business Emails, Sales-Related Materials, and User Manuals (Table 2).

3.1.4 Students' perceptions on the frequent use of specific Oral Communication Skills required in their program, ability to perform the skills and the extent the English courses help them to perform the skills.

The findings show that the most frequently used Oral Communication skills are (ranked from 'Always' to 'Never': Presentation And Public Speaking Skill, Attending Job Interview, Responding Appropriately To Questions, Expressing/Discussing Ideas/Information With Clarity And Organization, Explaining Information/Ideas/Opinions, Facilitating Group/Meetings/Discussions, Communicating With The Public Individually, Gathering And Probing For Information, Socializing, Counseling/Guiding/Advising Others On Options/Information/Issues, Communicating With The Public In Groups, Making Official Phone Calls, Using Diplomacy And Politeness, Corresponding With Business Partners, and Negotiating Effectively (Table 3).

The results on the ability to perform the skills reveal that the highest mean score is for Gathering and Probing For 
Information with the mean score of $M=3.07$, and the other four specific skills with the mean scores above average which are Presentation and Public Speaking Skill $M=2.63$, Communicating With The Public In Groups $M=2.61$, Socializing $M=2.59$, Attending Job Interview $M=2.54$. The skills with the lowest ability are Making Official Phone Calls and Counseling/Guiding/Advising Others On Options/Information/Issues, each with the mean score of $M=2.20$ (Table 3).

The extent the English courses help the students to perform the skills is ranked as follows (from 'A Lot' to 'Not At All'): Presentation And Public Speaking Skill, Responding Appropriately To Questions, Expressing/Discussing Ideas/Information With Clarity And Organization, Communicating With The Public In Groups, Facilitating Group/Meetings/Discussions, Explaining Information/Ideas/Opinions, Gathering And Probing For Information, Attending Job Interview, Communicating With The Public Individually, Socializing, Counseling/Guiding/Advising Others On Options/Information/Issues, Making Official Phone Calls, Using Diplomacy And Politeness, Negotiating Effectively, and Corresponding With Business Partners (Table 3).

\subsection{The Subject-specialists' Views on the Students'Language Lacks and Needs}

\subsubsection{Subject-specialists' perceptions on their students' general language skills and ability}

From the subject-specialists' point of view, it was discovered that the percentage for Reading is $85.7 \%$; Writing $85.7 \%$; Speaking 85.7\%; Listening 71.4\%; Grammar 42.9\%; Vocabulary 71.4\%. Hence, the subject-specialists rated Reading, Writing and Speaking Skill as having equal importance and at the top of the list to be acquired by their students, followed by Vocabulary and Listening and the least, Grammar.

The subject-specialists perceived their students as just below average in Reading $(M=2.43)$, Speaking $(M=2.29)$, Listening $(M=2.14)$, and weak in Vocabulary $(M=2.00)$, Grammar $(M=1.86)$ and Writing $(M=1.57)$.

3.2.2 Subject-specialists' perceptions on the frequent use of the specific Reading Skills required in their program and their students' ability to perform the skills.

The subject-specialists rated five specific Reading Skills as the most frequently used (100\%) in their program which are General Interest Articles, Posters, Sales-Related Materials, Official Notices, and User Manuals. This is followed by the next frequently used that are Company Brochures/Pamphlets, Technical Reports, and Business Letters, and then followed by Information Booklets, Specialist Articles, and Management Reports. The least used is MOU (Table 1).

On the ability of the students to perform the skills, the results reveal that the mean scores for all the specific reading skills are mostly average. Only one skill rated as above average which is Information Booklets with the mean score of $M=2.86$. The subject-specialists are of the opinion that their students are weak on skills like Management Reports and Specialist Articles with the mean, $M=2.00$ each (Table 1).

3.2.3 Subject-specialists' perceptions on the frequent use of the specific Writing Skills required in their program and their students' ability to perform the skills.

From the specific Writing Skills aspect, the subject-specialists rated three areas as the most frequently used (with 100\% score) which are General Interest Articles, Technical Reports and Posters. The next frequently used are Business Letters, and Official Notices, followed by Specialist Articles, Company Brochures/Pamphlets, Management Reports, Sales-Related Materials, Information Booklets, and User Manuals. The least used are MOU, and Formal Business Emails (Table 2).

Regarding their students' ability to perform the skills, the subject-specialists perceived their students as performing below average. The highest mean score is just $M=2.43$ which is for Posters. The students were also rated to perform badly in Management Reports and Formal Business Emails with the mean, $M=1.86$ each (Table 2).

3.2.4 Subject-specialists' perceptions on the frequent use of the specific Oral Communication Skills required in their program and their students' ability to perform the skills.

The subject-specialists highlighted two specific Oral Communication Skills as the most frequently applied in their program which are Explaining Information/Ideas/Opinions, and Communicating With The Public In Groups (with the score of 100\%). This is followed by Presentation And Public Speaking Skill, Facilitating Group/Meetings/Discussions, and Counseling/Guiding/Advising Others On Options/Information/Issues. Next, Using Diplomacy And Politeness, Negotiating Effectively, Responding Appropriately To Questions, Expressing/Discussing Ideas/Information With Clarity And Organization, Gathering And Probing For Information, Attending Job Interview, and Socializing. The least used are Making Official Phone Calls, and Corresponding with Business Partners (Table 3).

When the students' perceptions on the ability to perform the skills were tabulated, the results revealed that the subject-specialists rated their students as performing below average for all the skills. The highest score recorded is only $M=2.43$ for the skills of Facilitating Groups and/or Meetings/Discussions, Communicating With The Public In Groups, Making Official Phone Calls, Corresponding With Business Partners, Attending Job Interviews and Socializing (Table 3). 


\subsection{The English Language Instructors' Views on the Students' Language Lacks and Needs}

\subsubsection{English Language Instructors' perceptions on their students' general Language Skills}

The findings reveal that the English Language Instructors' rated Reading (score $=100 \%$ ) as the most important skill to be acquired by the students. This is followed by Writing $83.4 \%$; Speaking $83.4 \%$; Vocabulary $83.3 \%$; Listening $83.3 \%$; and Grammar $83.3 \%$.

\section{Discussion}

Comparatively, the subject-specialists, students and English Language Instructors differ in their view on the importance of each general language skill/component. The students viewed speaking $(75.6 \%)$, grammar $(53.7 \%)$ and vocabulary $(48.8 \%)$ skills in that order of importance. Meanwhile, the subject-specialists and English language instructors perceived reading, writing and speaking skills as the most important skills for students. General Language ability of the students is seen mostly as average by both the students and subject-specialists, even though, the students rated themselves as rather good in Reading. Nevertheless, both groups agreed that Grammar is the weakest component.

There seem to be differences in their views on the specific reading skills used in the program. The students stated that the most frequently used are Posters (70.7\%) and Technical Reports (68.3\%). While the least used specific reading skills are Business Letters (29.2\%) and Specialist Articles (24.4\%). By contrast, the subject-specialists stated that General Interest Articles, Posters, Sales-Related Materials and Official Notices as among the most frequently deal with in the program. They also viewed that MOU, and Formal Business Emails as the least used.

Most students viewed themselves as being competent in reading Posters $(M=2.78)$ as opposed to Reading Business Letters $(M=2.39)$. However, the subject-specialists viewed the students to perform better in Information Booklet $(M=$ $2.86)$ and the least is in Specialist Articles $(M=2.00)$.

In the specific Writing Skills, most students viewed their performance in writing Posters $(M=2.78)$ and Technical Reports $(M=2.63)$ as above average, while subject-specialists viewed the students' performance in writing those as below average. However, they also stated that the students are better at another specific skill which is Poster $(M=2.43)$, but that is still below average. The students also viewed themselves as performing the worst in writing Sales-Related Materials $(M=2.20)$ and User Manuals $(M=1.86)$. However, the subject-specialists rated Formal Business Emails $(M$ $=2.00)$ and Management Reports $(M=1.86)$ as the lowest.

In oral communication, both groups also differ in ranking the most frequently performed tasks in the program. The students claimed that Presentation And Public Speaking Skill as the most frequently performed. From the subject-specialists' point of view, Explaining Information/Ideas/Opinion and Communicating With The Public In Groups are the most frequently used in the program. However, both agree that Corresponding with Business Partners is one of the least used.

The oral communication ability of the students is assessed both by the students and the subject-specialists. From the findings, both have different opinions. The students stated that they have high abilities in Gathering and Probing For information $(M=3.07)$. However, to the subject-specialists, none of the Oral Communication Skills was rated above average.

From the findings on the extent the English Language courses help the students to perform the skills, it can be concluded that the courses did expose them to the skills. However, those exposures are not enough to develop their competency in the required skills. Most probably they would not be able to function well in their academic studies and career.

Regarding the English Language Instructors' responses based on the interview, all respondents answered 'No' when asked whether current English courses have prepared the students for the Industrial Design program or studies. In fact, they also suggested a new English course that is relevant to the program in which emphasis should be given to help the students to acquire the specific areas of Reading, Writing and Oral Communication Skills. Collaboration between subject-specialists and English language instructors does not exist so far and this can be a problem to determine and share the problems faced by the students.

The students' ability in communicating using the target language is considered poor and their performance in reading, writing, listening and speaking is average. They stressed that it is also important for the students to acquire good English language proficiency in order to do well in their studies. The specific skills of English language that the students use in the program are speaking, writing and reading.

\section{Conclusion}

In conclusion, the findings of the three groups of respondents collected based on the questionnaires and interview, have revealed that the lacks and needs of the students can be different and considered inaccurate when compared to the 
subject-specialists and the English language instructors. Therefore, it is valid and important to get or rely on more than one perception as to ensure the validity of data and findings before making any conclusion and revealing any results.

The subject-specialists for instance, have given some insights regarding the students' needs of academic language skills. They have indirectly given the idea about what is needed by the program from the students in order to perform successfully and most of the students were seen as still weak in most of the important skills. In addition, the students are also found to lack many of the sub-language skills in the three areas of language skills that are very much required by the program, yet the students did not do well such as: Reading - reading of General Interest Materials, and Sales-Related Materials; Writing - writing of General Interest Materials and Technical; Oral communication - skills of Explaining Information/Ideas/Opinions, and Communicating with the public in groups.

The results expose that the students in fact have some difficulties when performing tasks that are related to their program as relevant language skills are needed for that purpose. They might have claimed that they can perform the skills assigned by the instructors. However, their performance has been commented on by the instructors as needing more improvement. They require more exposure to it or more practice.

The English language instructors meanwhile responded that the current English Language courses also have not contributed much towards enhancing the students' language skills. There are still many other components to cover to make them relevant and to fulfill the requirements of the Industrial Design program. The findings of this study have also suggested some sub-skills of the main language skills that need to be introduced in English Language courses specifically for the Industrial Design students.

The researchers believe that this study has revealed such result due to the lack of interactions between the subject-specialists and the English language instructors. Hence, the subject-specialists should work together with the English language instructors in helping the students to understand the technical and language aspects better. They should also understand the Industrial Design students' strengths and weaknesses. The subject-specialists can help the English language instructors to improve the English language skills among the Industrial Design students by providing them with the input of their students' strengths and weaknesses especially on areas or topics that require more language competencies in order to enable them to perform well in their field.

Besides, the subject-specialists can help the Language faculty to devise a new syllabus to meet the requirements of the Industrial Design faculty. Through this, it is hoped that the Language faculty would be able to produce language courses that would cater to the needs of the Industrial Design students. It is also hoped that this collaboration between the two faculties will help the students to perform better and be more competent in their field.

\section{References}

Blue, G.M. (Undated) Determining the language learning needs of students of art anddesign. . (Undated). [Online] Available at: http://www.alladin.ac.uk/SUPPORT/downloads/langLearNedds.doc.

Dudley-Evans, T. and St. John. (1998). Developments in English for specific purposes: A multi-disciplinary approach. UK: Cambridge University Press.

Hutchinson, T, and Waters, A. (1995). English for specific purposes: A learning-centred approach. New York, USA: Cambridge University Press.

Jordan, R.R. (1997). English for academic purposes: A guide and resource book for teachers. UK: Cambridge University Press.

Khairi Izwan Abdullah et al. (1993). ESP in Malaysia: An Overview. ESP Malaysia. Vol 1, Issue1, p. 61-72.

Suzana Ab. Rahim. (2005). A Study on the Needs of Communication Skills of the Engineering Undergraduates at UiTM Penang. Unpublished Masters Thesis. Universiti Sains Malaysia.

Seedhouse, P. (1995). Needs analysis and the General English classroom. ELT Journal.Vol. 49, No.1, p. 59-64.

Wan Irham Ishak. (2002). EAP English Language Needs Analysis of Engineering Students in Higher Education. Unpublished Masters Thesis. Universiti Putra Malaysia. 
Table 1. The results on both the students and subject-specialists' perceptions of frequent use of specific reading skills in their program, ability to perform the skills and the extent the English courses help the students to perform the skills

\begin{tabular}{|l|c|c|c|c|c|}
\hline \multirow{2}{*}{ Reading Skills } & \multicolumn{3}{|c|}{ Students' Perceptions } & \multicolumn{2}{c|}{ Subject-specialists'Perceptions } \\
\cline { 2 - 6 } & Use(\%) & Ability $(M)$ & Extent(\%) & Use(\%) & Ability $(M)$ \\
\hline MOU & 43.9 & 2.56 & 56.1 & 57.2 & 2.29 \\
\hline General interest articles & 46.3 & 2.68 & 63.4 & 100 & 2.43 \\
\hline Specialist articles & 24.4 & 2.46 & 65.8 & 71.4 & 2.00 \\
\hline Formal business emails & 34.1 & 2.44 & 39.1 & 57.2 & 2.29 \\
\hline Company brochures/pamphlets & 63.4 & 2.83 & 65.9 & 85.7 & 2.57 \\
\hline Technical reports & 68.3 & 2.76 & 56.1 & 85.7 & 2.14 \\
\hline Management reports & 56.1 & 2.44 & 51.3 & 71.5 & 2.00 \\
\hline Posters & 70.7 & 2.98 & 73.2 & 100 & 2.57 \\
\hline Business letters & 29.2 & 2.39 & 53.9 & 85.7 & 2.14 \\
\hline Sales-related materials & 43.7 & 2.46 & 48.8 & 100 & 2.14 \\
\hline Official notices & 42.5 & 2.80 & 51.3 & 100 & 2.57 \\
\hline Info. booklets & 48.8 & 2.71 & 75.6 & 71.5 & 2.86 \\
\hline User manuals & 43.9 & 2.71 & 60.9 & 100 & 2.43 \\
\hline
\end{tabular}

Table 2. The results on both the students and subject-specialists' perceptions of frequent use of specific writing skills in their program, ability to perform the skills and the extent the English courses help the students to perform the skills

\begin{tabular}{|l|c|c|c|c|c|}
\hline \multirow{2}{*}{ Writing Skills } & \multicolumn{3}{c|}{ Students' Perceptions } & \multicolumn{2}{c|}{ Subject-specialists'Perceptions } \\
\cline { 2 - 6 } & Use(\%) & Ability $(M)$ & Extent $(\%)$ & Use $(\%)$ & Ability $(M)$ \\
\hline MOU & & & & 57.2 & 2.00 \\
\hline General interest articles & 41.5 & 2.41 & 68.3 & 100 & 2.00 \\
\hline Specialist articles & 39.0 & 2.24 & 56.1 & 71.4 & 2.00 \\
\hline Formal business emails & 24.4 & 2.27 & 46.4 & 57.2 & 1.86 \\
\hline Company brochures/pamphlets & 46.3 & 2.51 & 56.1 & 71.4 & 2.14 \\
\hline Technical reports & 68.3 & 2.63 & 56.1 & 100 & 2.00 \\
\hline Management reports & 56.1 & 2.37 & 61.0 & 71.4 & 1.86 \\
\hline Posters & 70.7 & 2.78 & 60.9 & 100 & 2.43 \\
\hline Business letters & 29.2 & 2.46 & 51.3 & 85.7 & 2.00 \\
\hline Sales-related materials & 43.9 & 2.20 & 46.3 & 71.4 & 2.00 \\
\hline Official notices & 41.5 & 2.27 & 51.2 & 85.7 & 2.14 \\
\hline Info. booklets & 48.8 & 2.56 & 53.7 & 71.4 & 2.29 \\
\hline User manuals & 43.9 & 2.22 & 46.3 & 71.4 & 2.00 \\
\hline
\end{tabular}

Table 3. The results on both the students and subject-specialists' perceptions of frequent use of specific speaking and listening skills in their program, ability to perform the skills and the extent the English courses help the students to perform the skills

\begin{tabular}{|l|c|c|c|c|c|}
\hline \multirow{2}{*}{ Speaking and Listening Skills } & \multicolumn{3}{|c|}{ Students' Perceptions } & \multicolumn{2}{c|}{ Subject-specialists' Perceptions } \\
\cline { 2 - 6 } & Use(\%) & Ability $(M)$ & Extent(\%) & Use(\%) & Ability(M) \\
\hline Presentation and public speaking skills & 78.1 & 2.63 & 80.5 & 85.7 & 2.29 \\
\hline $\begin{array}{l}\text { Facilitating and/or } \\
\text { meetings/discussions }\end{array}$ & 53.6 & 2.51 & 68.3 & 85.7 & 2.43 \\
\hline Explaining info., ideas, opinions & 58.5 & 2.51 & 65.9 & 100 & 2.29 \\
\hline Using diplomacy and politeness & 41.4 & 2.22 & 48.8 & 71.5 & 2.14 \\
\hline Negotiating effectively & 29.3 & 2.22 & 41.5 & 71.5 & 2.14 \\
\hline Responding appropriately to questions & 68.3 & 2.41 & 75.6 & 71.5 & 2.29 \\
\hline $\begin{array}{l}\text { Communicating with the public in groups } \\
\text { (team work) }\end{array}$ & 46.3 & 2.61 & 68.3 & 100 & 2.43 \\
\hline $\begin{array}{l}\text { Communicating with the public } \\
\text { individually }\end{array}$ & 51.2 & 2.51 & 60.9 & 57.2 & 2.29 \\
\hline $\begin{array}{l}\text { Expressing/discussing ideas and info. with } \\
\text { clarity and organization }\end{array}$ & 58.6 & 2.46 & 68.3 & 71.5 & 2.14 \\
\hline $\begin{array}{l}\text { Counseling/guiding/advising others on } \\
\text { options, info., issues }\end{array}$ & 46.4 & 2.20 & 56.1 & 85.7 & 2.29 \\
\hline Gathering and probing for information & 48.8 & 3.07 & 63.4 & 71.5 & 2.14 \\
\hline Making official phone calls & 41.6 & 2.20 & 49.2 & 42.9 & 2.43 \\
\hline Corresponding with business partners & 39.2 & 2.44 & 36.6 & 42.9 & 2.43 \\
\hline Attending job interviews & 70.8 & 2.54 & 61.0 & 71.5 & 2.43 \\
\hline Socializing & 48.8 & 2.59 & 58.5 & 71.5 & 2.43 \\
\hline
\end{tabular}




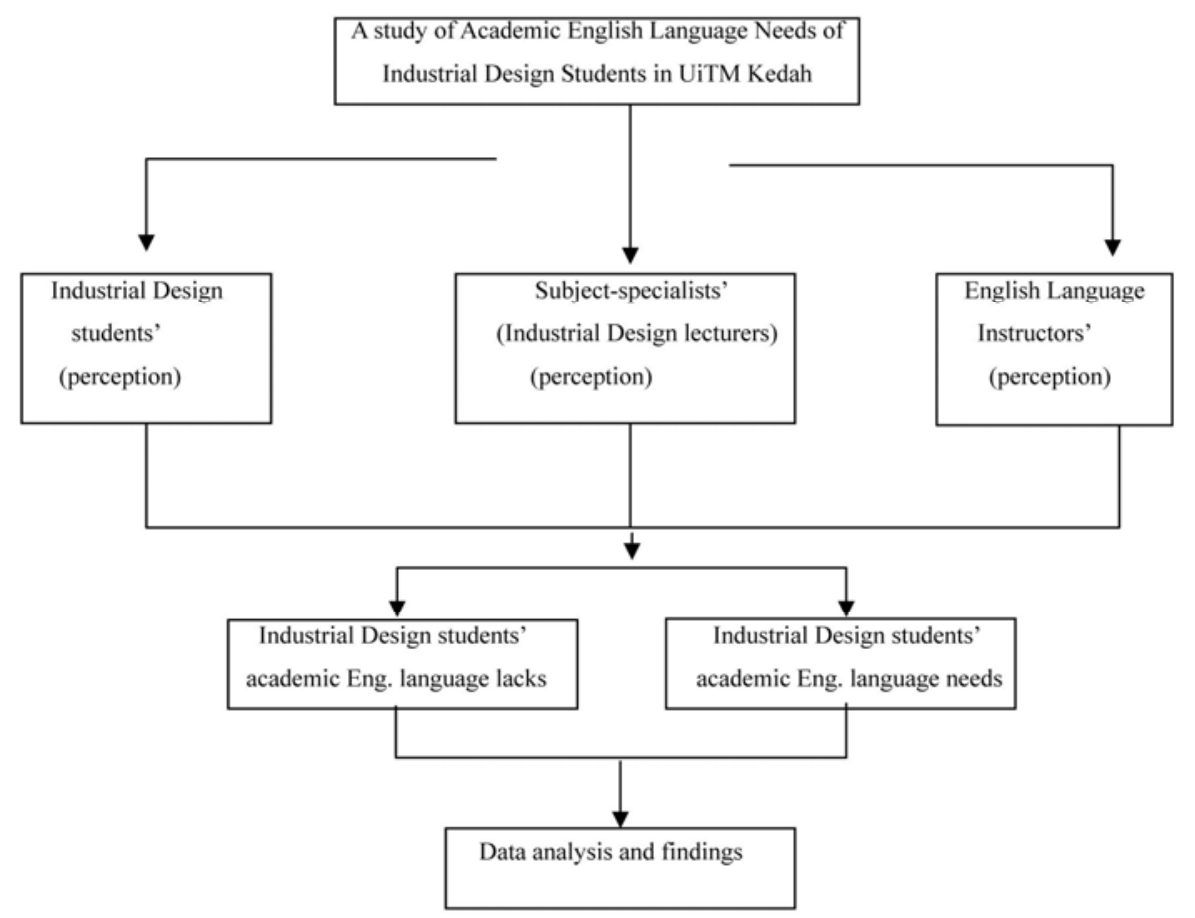

Figure 1. Conceptual Framework - (Dudley-Evans and St. John (1998:125) 